\title{
METAGENOMICS-BASED CLONING OF AMILASE-ENCODING GENES FROM THE UNCULTURED SYMBIOTIC BACTERIA OF A MARINE SPONGE Theonella swinhoei FROM KAPOPOSANG ISLAND, SOUTH SULAWESI
}

\author{
Franciscus E. Priyono', Dewi Seswita Zilda², Yudi Kusnadi², Tri A. Hadi \\ Irvina Nurrachmi ${ }^{1}$, and Agustinus Robert Uria ${ }^{2}$ \\ ${ }^{1}$ Faculty of Fisheries and Marine Sciences, University of Riau, Pekanbaru, \\ ${ }^{2}$ Research Center for Marine and Fisheries Product Processing and Biotechnology, \\ Jalan KS. Tubun Petamburan VI, Slipi, Central Jakarta 10260, Indonesia \\ ${ }^{3}$ Research Center for Oceanography, Indonesian Institute of Sciences (LIPI), Jakarta, Indonesia \\ Article history: \\ Received: 11 December 2016; Revised: 5 April 2017; Accepted: 26 April 2017
}

\begin{abstract}
Marine sponges have recently been recognized as the source of enzymes, including members of hydrolases. Hydrolytic enzymes are extracellularly produced by sponge-associated bacteria to mediate the metabolism of complex organic matters, there by assisting the sponge hosts in nutrition and metabolic processes. Among hydrolytic enzymes, amilases has attracted increasing attention due to their potential industrial applications. This research work was aimed to utilize functional metagenomics approach for the discovery of amilases derived from the uncultured symbiotic bacteria of the Indonesian marine sponge Theonella swinhoei. We initially constructed a small-insert metagenomic library in Escherichia coli by cloning of metagenome in the size range of 5-20 kb prepared from the sponge's microbiome. Further functional screening of the resulting metagenomic library led to the isolation of two recombinant $E$. coli clones potentially harboring amilase genes, as indicated by the presence of clearing zones surrounding the selective medium containing $1 \%$ amilum.
\end{abstract}

Keywords: Theonella swinhoei, Uncultured symbiotic bacteria, DNA cloning, amylase gene

\section{Introduction}

Marine sponges are a rich source of structurally diverse and unique compounds with potent biological activities. Symbiotic bacteria associated with marine sponges have been proposed as the actual producers of these bioactive compounds (Uria \& Piel, 2009). Recently, a number of hydrolytic enzymes have been reported to be secreted by sponge-associated bacteria, exemplified by amylase, protease, deoxyribonuclease, gelatinase, lipase, phosphate, urease (Feby \& Nair, 2010), chitosanase (Chasanah et al., 2009), and Chitinase (2005). Such extracellular hydrolytic enzymes may mediate the metabolism of complex organic matters, thereby assisting the host in nutrition and various metabolic processes (Marx et al., 2007). Among hydrolytic enzymes, amylases belong to the most useful enzymes in various industrial processes, including food, textile, paper, and detergent industries (Pandey et al., 2003). Bacterial amylases particularly exhibit potential applications in pharmaceutical and fine-chemical industries (Gupta et al., 2003).

The general approach of searching for microbial enzymes with desired activities is screening of natural diversity for hitherto unknown enzymes based on traditional cultivation-dependent microbiological methods that generally consist of isolation of pure cultures, screening of microbial isolates expressing desired enzymatic activity, characterization of the isolated enzymes of interest, and optimizing the enzyme production and recovery (Lämmle et al., 2007; Uria \& Zilda, 2016). The fact that the vast majority of symbiotic bacterial consortia of marine sponges are amenable to cultivation (Amann et al., 1995; Hugenholtz et al., 1998; Webster and Hill, 2001) has

${ }^{*}$ Corresponding author.

E-mail: agustinus.uria@gmail.com; agustinus.uria@kkp.go.id 
encouraged us to employ cultivation-independent approach, called metagenomics, to gain access to hydrolytic enzymes produced by uncultured bacterial symbionts. In this work, we showed how functional metagenomics approach can be used for the direct heterologous expression of amylase genes captured from the sponge's metagenome. This approach developed in this work facilitates the economical bulk production of the target enzyme, and furthermore provides a basis for protein engineering to generate mutated variants with desired characteristics more suitable for industrial applications.

\section{Material and Methods}

\subsection{Sponge Collection and Identification}

A sponge specimen was collected from reefs at the depth range of 5-10 m in Kapoposang Island, Indonesia on September 2015. Seawater (1 L) was sterilized by filtration on $0.45-\mu \mathrm{m}$ and $0.22-\mu \mathrm{m}$ membranes. The sponge sample ( $10 \mathrm{gram}$ ) was sliced into small pieces and stored in $70 \%$ ethanol diluted with such sterile seawater. For the identification of sponge specimen, histological analysis of the sponge tissue was conducted using light microscopy (Hooper, 2003) which consisted of spicule preparation and section preparation. Small fragments of the tissue from inner and outer sides were placed into a $10 \mathrm{ml}$ bottle. A small portion of bleaching agent containing sodium hypochlorite was added to the fragment and waited for a short period to dissolve the organic tissues, leaving only mineral skeleton (spicules). Then, it was washed by replacing the bleaching agent with water for several times. Next, clean spicule suspensions were sucked and pipetted onto an object glass. Finally, it was covered using cover glass carefully to keep the spicule in their original shapes. Sponge was cut in a cross section then sliced about $1 \mathrm{~mm}$ thick. Then the thin slice was placed onto an object glass. To make it observable, then several small drops of water were added to the slice and then covered with the cover glass.

\subsection{Preparation of Microbiome and Metagenome}

A small sample piece $(2.5 \mathrm{~g})$ was squeezed with $10 \mathrm{ml}$ of sterile seawater in a $50-\mathrm{ml}$ falcon tube, mixed by vortex, and let at room temperature for a few minutes. The resulting supernatant was transferred to five $2 \mathrm{ml}$ microtube vials and centrifuged at 500 rpm (rotor number FP 241.5 P) for 10 minutes using Microfuge $22^{\circledR}$ (Beckman Coulter, US). The microbial cell pellet in each vial was resuspended with $1 \mathrm{ml}$ of $\mathrm{ddH}_{2} \mathrm{O}$ and stored at $-20{ }^{\circ} \mathrm{C}$ for DNA isolation.
Metagenomic DNA was prepared from the isolated microbiome using Ctyl-Trimethyl Ammonium Bromide $10 \%$ (CTAB) method (Piel et al., 2004) with a slight modification.

\subsection{Construction of a Metagenomic Library}

The metagenomic DNA obtained from uncultured microbiome was separated on $1 \%$ Low Melting Point (LMP) agarose gel. DNA fragments in the size range of 5-20 kb were repaired at both ends using End-It ${ }^{\mathrm{TM}}$ DNA End-Repair Kit (Epicentre, Germany) and subsequently ligated with pJET1.2/blunt vector (Thermo Scientific, USA) according to the manufacturer's protocol. The ligated vector was transformed into E. coliDH5 $\alpha$ using a Gene Pulsery Electroporator (Bio-Rad, USA). The transformed cell suspension was plated on Luria Broth (LB) media containing $100 \mu \mathrm{g} / \mathrm{ml}$ ampicillin.

\subsection{Screening of a Metagenomic Library}

Screening of a metagenomic library for amylolytic activities was carried out by transferring the recombinant colonies on to new LB media containing $1 \%$ soluble starch, $100 \mu \mathrm{g} / \mathrm{ml}$ ampicillin and $1 \% \mathrm{CaCl}_{2}$. After overnight incubation at $37^{\circ} \mathrm{C}$, the LB plates were stained with $\mathrm{I}_{2}-\mathrm{KI}$ solution ( $5 \% \mathrm{w} / \mathrm{v}$ iodine, $10 \% \mathrm{w} / \mathrm{v}$ potassium iodide). Amylase activity of transformed colonies was indicated by a clearing zone around them.

\subsection{Amylase Assay}

Amylase activity assay was carried out by mixing $100 \mu \mathrm{l}$ enzyme solution with one $\mathrm{ml}$ of $1 \%$ soluble starch in $50 \mathrm{mM}$ phosphate buffer $\mathrm{pH}$ 7. The mixture was incubated for $10 \mathrm{~min}$ at $37^{\circ} \mathrm{C}$, and then terminated by adding $2 \mathrm{ml}$ of DNS reagentand heating at $100^{\circ} \mathrm{C}$ for $10 \mathrm{~min}$. After cooling the terminated reaction, optical density of each sample was spectrophotometrically measured at $540 \mathrm{~nm}$ (Sjofjan \& Ardyati, 2011). Enzyme activity was expressed in unit, in which one unit amount of mole glucose released by enzyme under the assay condition. Protein concentration was determined by the method of Bradford (1976) using bovine serum albumin as a standard. For measuring the amylase activity, TP-20-2 was initially cultivated in liquid LB containing $100 \mu \mathrm{g} / \mathrm{ml}$ ampicillin, $1 \%$ starch, and $0.1 \% \mathrm{CaCl}_{2}$. Then the cell-free supernatant was prepared from the culture and used for amylase assay.

\section{Results and Discussion}

Hydrolytic enzymes, such as amylase, are widely applied in various industrial processes, ranging from 


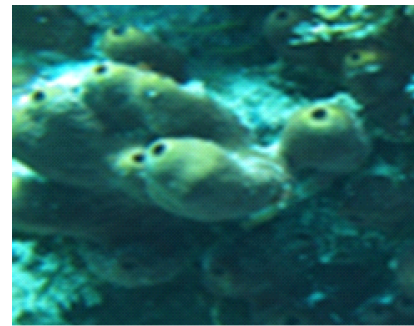

A

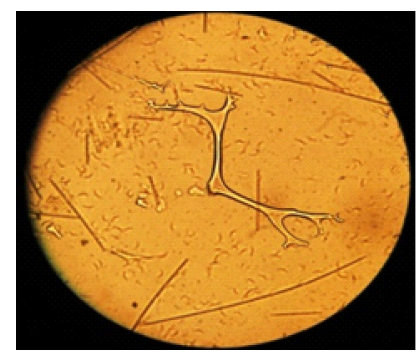

D

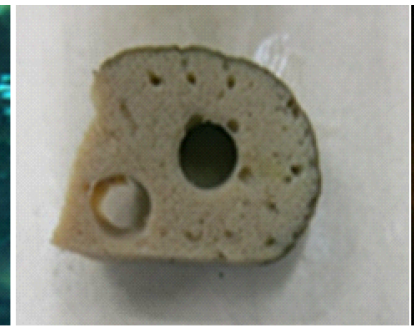

B

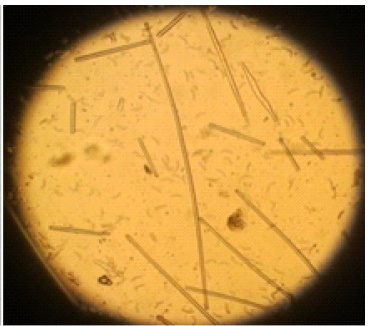

C

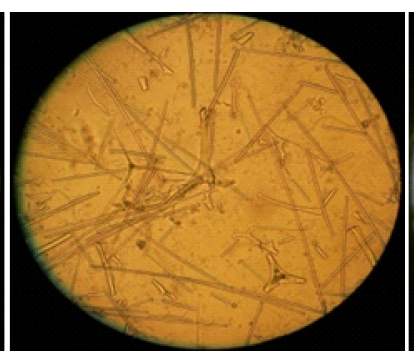

$\mathrm{E}$

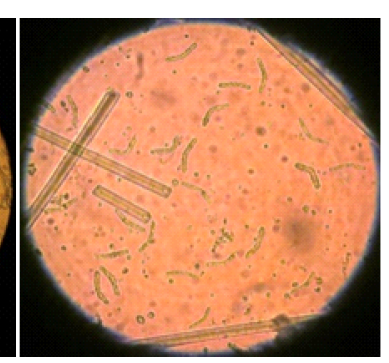

$\mathrm{F}$

Figure 1. Identification of a sponge specimen investigated in this work. Morphology of the specimen underwater $[A]$ and upon collection $[B]$. Histological analysis showed megascleres consisting of strongylote $[C$, E], phyllotriane [D, E], and rhabdome [F].

foods, beverages, textile and leather processing. Most of enzymes used in the industry are derived from microorganisms because microbial enzymes are relatively more stable and active than the corresponding enzymes derived from plants and animals (Zhang \& Kim, 2010). In the programs to search for novel hydrolytic enzymes, we investigated the uncultured symbiotic microbiome of an Indonesian marine sponge collected in Kapoposang Island through functional metagenomic approach.This functional metagenomics was particularly directed on detection of the expressed amylases encoded on the microbiomes metagenome. Therefore the success of this approach depends on the compatibility of the cloned genes with the expression machinery of the heterologous host E. coli (Uria \& Zilda, 2016).

\subsection{Identity of the Sponge Specimen}

We initially identified the sponge specimen used in this work. Morphological observation showed that it was irregular massive and cone-shaped with expanded amorphous basal part (Figure 1A). The diameter was about 8-10 mm (Figure 1B). Its color was light brown. Histological analysis indicated the presence of three types of megascleres as well as skeleton from cross section (Figure 1C-F). These morphological and histological characters indicated its identity as Theonella swinhoei. This morphological character is different from the holotype of T. swinhoei Gray described by Gray (1868).

\subsection{Detection of Starch-Degrading Clones}

We initially generated a plasmid-based metagenomic library with the insert size range of 5 to $20 \mathrm{~kb}$. The resulting library was then screened on the selective media containing soluble starch. Colonies capable of degrading starch were visualized using lodine solution. As shown in Figure 2, several recombinant colonies exhibited a clearing zone.

Amylolytic index (Al) values of individual starchdegrading colonies were listed in Table 1 . Al value is the ratio of clear zone diameter formed by a colony and its colony diameter. The presence of a clearing zone after iodine staining indicated that the positive clones secreted amylases extracellularly secreted to degrade amylum contained in the media. The amylases may be encoded on the genes present in the plasmid.

Among positive colonies, one representative colony showing the highest AI values (TP-20-2) were selected for further analysis. The positive clone was streaked on new selective media to confirm their ability to degrade starch. As shown in Figure 3 the clone TP20-2 with the highest Al exhibited a large halo that was not observed for the negative clone (E. coli containing vector without insert). It was cultivated overnight, and the recombinant plasmid was prepared from the culture.

To confirm the presence of insert, such recombinant plasmids were digested with $\mathrm{Bg} / \mathrm{ll}$. The 


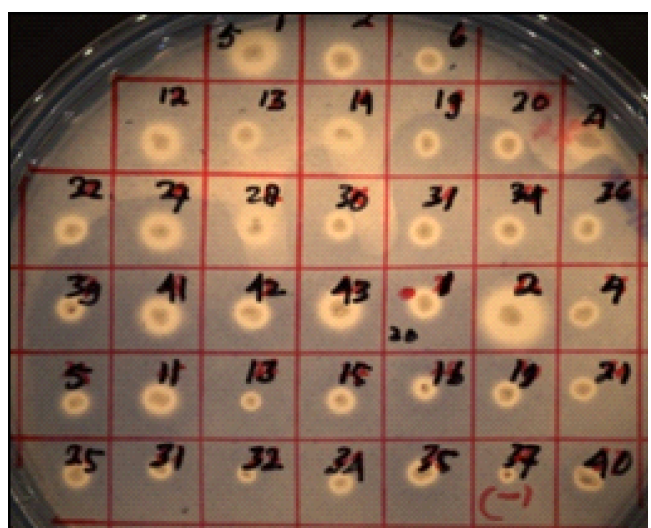

Figure2. Identifying recombinant $E$. coliclones capable of degrading soluble starch contained in the media. Positive clones were indicated by a clear zone.

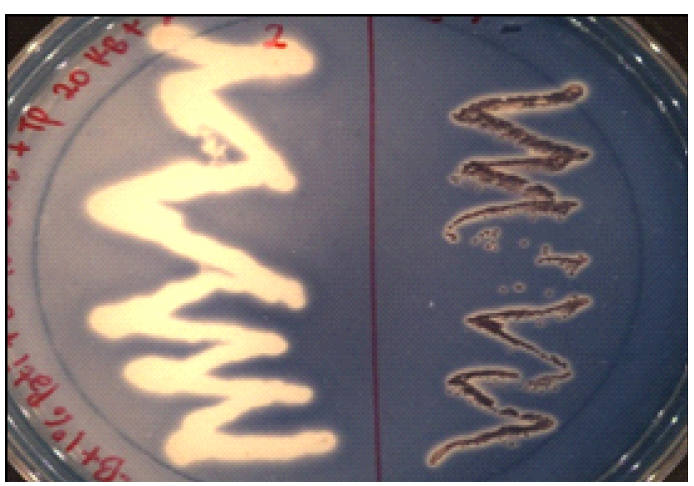

Figure 3. The ability of the clone TP-20-2 to degrade starch was shown by significant clear cone. The negative control is E. coli clone harboring the same plasmid as that in TP-20-2, but it contained no insert.

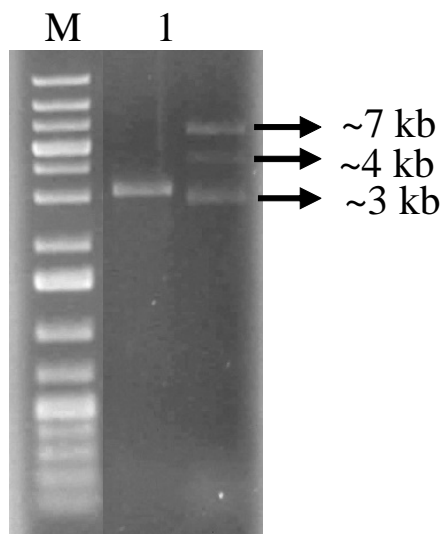

Figure 4. Digestion of TP-20-2 with Bgll showed an insert of approximately $11 \mathrm{~kb}$. This suggests that $B g / l$ restriction occured inside the insert, resulting two DNA fragments ( 4 and $\sim 7 \mathrm{~kb})$. M is marker, 1-kb plus DNA ladder, lane 1 is the negative control, and lane 2 is the TP-20-2 digested with Bgll.

digestion product was separated on the $1 \%$ agarose gel, clearly showing two additional DNA fragments above the $\sim 3-k b$ vector backbone. This suggests that the plasmid construct present in TP-20-2 harbored an insert of approximately $11 \mathrm{~kb}$, consisting of two DNA fragments ( $4 \mathrm{~kb}$ and $\sim 7 \mathrm{~kb}$ ).

The insert present in TP-20-2 construct was sequenced using the primer pair in the pJET1.2/blunt. 
Table 1. Amylolytic Index (Al) of recombinant clones

\begin{tabular}{cccc}
\hline Clone code & $\begin{array}{c}\text { Amylolytic } \\
\text { Index }\end{array}$ & Clone code & $\begin{array}{c}\text { Amylolytic } \\
\text { Index }\end{array}$ \\
\hline TP-5-1 & 0.75 & TP-20-1 & 0.5 \\
TP-5-2 & 0.52 & TP-20-2 & 1.15 \\
TP-5-6 & 0.42 & TP-20-4 & - \\
TP-5-12 & 0.62 & TP-20-5 & - \\
TP-5-13 & 0.50 & TP-20-11 & 0.57 \\
TP-5-14 & 0.60 & TP-20-13 & - \\
TP-5-19 & 0.50 & TP-20-15 & 0.52 \\
TP-5-20 & 0.47 & TP-20-16 & 0.45 \\
TP-5-21 & 0.67 & TP-20-19 & - \\
TP-5-22 & 0.50 & TP-20-21 & - \\
TP-5-27 & 0.72 & TP-20-25 & 0.5 \\
TP-5-28 & 0.60 & TP-20-31 & - \\
TP-5-30 & 0.50 & TP-20-32 & - \\
TP-5-31 & 0.50 & TP-20-34 & - \\
TP-5-34 & 0.52 & TP-20-35 & 0.57 \\
TP-5-36 & 0.52 & TP-20-37 & - \\
TP-5-39 & 0.50 & TP-20-40 & - \\
TP-5-41 & 0.70 & TP-20-41 & 0.45 \\
TP-5-42 & 0.55 & & \\
TP-5-43 & 0.70 & & \\
\hline
\end{tabular}

If it is necessary, primer walking or sub-cloning would be conducted to enable sequence the remaining unsequenced parts of the insert.

\section{Conclusion}

Cultivation-independent approach had been successfully used to screen amylase genes from the uncultured microbiome of the marine sponge Theonella swinhoei. This preliminary work found that by functional metagenomics developed in this work, one of the starch-degrading recombinant $E$. coli clones, designated as TP-20-2, exhibiting the highest amylotic index was selected for further studies.

\section{Acknowledgement}

We are grateful to Nurrahmi D. Fajarningsih, Hedi Indra Januar, Sri Iswani and Nurmaya Legistari for help during the sponge sample collection and processing. This work was facilitated by Research Center for Marine and Fisheries Product Processing and Biotechnology, Slipi, Jakarta Pusat, and financially supported by National Budget (APBN) given to RCMFPPB through Ministry of Marine Affairs and Fisheries, Republic of Indonesia.

\section{References}

Amann, R.I., Ludwig, W., and Schleifer, K.H. (1995). Phylogenetic identification and in situ detection of individual microbial cells without cultivation. Microbiol.Rev. 59(1):143-169.

Bradford M.M., (1976) A rapid and sensitive method for the quantification of microgram quantities of protein utilizing the principle of protein-dye binding. Analytical Biochemistry 72, 248-254.

Chasanah E., Zilda D.S., and Uria A.R. (2009). Screening and characterization of bacterial chitosanase from marine environment. Journal of Coastal Development 12 (2):64-72.

Feby A., and Nair S. (2010). Sponge-associated bacteria of Lakshadweep coral reefs, India: resource for extracellular hydrolytic enzymes. Advances in Bioscience and Biotechnology 1:330-337.

Friedrich A.B.I., Fischer P., Proksch J., Hacker., and U. Hentschel. (2001). Temporal variation of the microbial community associated with the Mediterranean 
sponge Aplysina aerophoba. FEMS Microbiol. Ecol. 38(2-3):105-113.

Gray J.S. (1868). Note on Theonella, a new genus of coralloid sponges from Formosa. Proceedings of the Zoological Society of London (3): 565-566.

Gupta R., Gigras P., Mohapatra H., Goswami V.K., and Chauhan B. (2003). Microbial á-amylases: a biotechnological perspective. Process Biochem. 38:1599-1616.

Hooper J.N.A. (2003). Sponguide: guide to sponge collection and identification. Queensland Museum, Brisbane. 26pp.

Hugenholtz P., Goebel B.M., and Pace N.R. (1998). Impact of culture-independent studies on the emerging phylogenetic view of bacterial diversity.J. Bacteriol. 180(18):4765-4774.

Marx J.C., Collins T., D’Amico, S., Feller, G. and Gerday, C. (2007).Cold-adapted enzymes from marine antarctic microorganisms. Marine Biotechnology, 9(3):293-304.

Pandey A., Nigam P., Soccol C.R., Soccol V.T., Singh D., and Mohan R. (2003). Advances in microbial amylases. BiotechnolApp/Biochem. 31 (Pt 2):135152.

Pabel C. T., Joachim V., Wilde C., Franke P., Hofemeister J., Adler B., Bringmann G., Hacker J., and Hentschel V. 2003. Antimicrobial activities and matrix assisted laser desorption/ ionization mass spectrometry of Bacillus isolated from the marine spons Aplysina aerophoba. Marine Biotechnology.p. 424-434.

Sanger F., Nicklen S., and Coulson A.R. (1977). DNA sequencing with chain-terminating inhibitors. Proc Natl Acad Sci USA 74, 5463-5467.
Sjofjan O., and Ardyati T. (2011). Extracellular amylase activity of amylolytic bacteria isolated from quail's (Coturnix japonica) intestinal tract in corn flour medium. International Journal of Poultry Science 10 (5): 411-415, 2011.

Taylor M.W., Radax R., Steger D., Wagner M. (2007)..Sponge-associated microorganisms: evolution, ecology, and biotechnological potential. Microbiol Mol Biol Rev. 71:295-347.

Uria A.R., and Piel J. (2009). Cultivation-independent approaches to investigate the chemistry of marine symbiotic bacteria. Phytochemistry Rev. 8:401-414.

Uria A.R., and Chasanah E. (2005). Chitinase and chitosanase from microorganisms associated with marine sponges. Proceeding of the $9^{\text {th }}$ ASEAN Food Conference on 8-9 ${ }^{\text {th }}$ August 2015 in Jakarta.

Uria A.R., and Zilda D.S. (2016). Metagenomics-guided mining of commercially useful enzymes from marine microorganisms. Chapter - Advances in Food and Nutrition Research in the book "marine enzymes biotechnology: production and industrial applications, part I"- published by Elsevier. doi:10.1016/bs.afnr.2016.05.001.

Vaseekaran, S., Balakumar, S., and Arasaratnam, V. 2010. Isolation and Identification of a bacterial strain producing thermostable á-amylase.Tropical Agricultural Research 22: 1, 1-11.

Webster N.S., and Hill R.T. (2001). The culturable microbial community of the great barrier reef sponge Rhopaloeidesodorabile is dominated by an áproteobacterium. Mar. Biol. (Berl) 138:843-851.

Zhang C., and Kim S-K. (2010). Research and application of marine microbial enzymes: status and prospects. Mar. Drugs 8(6): 1920-1934. 